\title{
Mapping and Characterization of HCMV-Specific Unconventional HLA-E-Restricted CD8 T Cell Populations and Associated NK and T Cell Responses Using HLA/Peptide Tetramers and Spectral Flow Cytometry
}

\author{
Amélie Rousselière, Laurence Delbos, Céline Bressollette $\mathbb{D}^{D}$, Maïlys Berthaume and Béatrice Charreau *D \\ INSERM, Center for Research in Transplantation and Translational Immunology, Nantes Université, UMR 1064, \\ CHU Nantes, F-44000 Nantes, France; amelie.rousseliere@etu.univ-nantes.fr (A.R.); \\ Laurence.Delbos@univ-nantes.fr (L.D.); celine.bressollette@chu-nantes.fr (C.B.); \\ mailys.berthaume@etu.univ-nantes.fr (M.B.) \\ * Correspondence: Beatrice.Charreau@univ-nantes.fr; Tel.: +33-240-087-416
}

check for updates

Citation: Rousselière, A.; Delbos, L.; Bressollette, C.; Berthaume, M.;

Charreau, B. Mapping and

Characterization of HCMV-Specific

Unconventional HLA-E-Restricted

CD8 T Cell Populations and

Associated NK and T Cell Responses Using HLA/Peptide Tetramers and Spectral Flow Cytometry. Int. J. Mol. Sci. 2022, 23, 263. https://doi.org/ $10.3390 /$ ijms 23010263

Academic Editors: Manlio Ferrarini and Patricia Price

Received: 4 November 2021

Accepted: 22 December 2021

Published: 27 December 2021

Publisher's Note: MDPI stays neutral with regard to jurisdictional claims in published maps and institutional affiliations.

Copyright: (c) 2021 by the authors. Licensee MDPI, Basel, Switzerland. This article is an open access article distributed under the terms and conditions of the Creative Commons Attribution (CC BY) license (https:// creativecommons.org/licenses/by/ $4.0 /)$.

\begin{abstract}
HCMV drives complex and multiple cellular immune responses, which causes a persistent immune imprint in hosts. This study aimed to achieve both a quantitative determination of the frequency for various anti-HCMV immune cell subsets, including CD8 T, $\gamma \delta \mathrm{T}$, NK cells, and a qualitative analysis of their phenotype. To map the various anti-HCMV cellular responses, we used a combination of three HLA $_{\text {peptide }}$ tetramer complexes (HLA-E VMAPRTLIL, HLA-E $_{\text {VMAPRSLLL, and }}$ HLA-A2 NLVPMVATV) and antibodies for 18 surface markers (CD3, CD4, CD8, CD16, CD19, CD45RA,

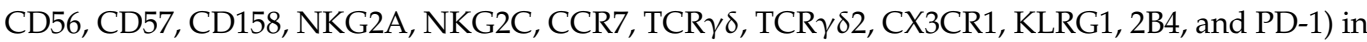
a 20-color spectral flow cytometry analysis. This immunostaining protocol was applied to PBMCs isolated from $\mathrm{HCMV}^{-}$and $\mathrm{HCMV}^{+}$individuals. Our workflow allows the efficient determination of events featuring HCMV infection such as CD4/CD8 ratio, CD8 inflation and differentiation, HCMV peptide-specific HLA-E $\mathrm{EL}_{40}$ and HLA-A2 ${ }_{\mathrm{pp} 65} \mathrm{CD} 8 \mathrm{~T}$ cells, and expansion of $\gamma \delta \mathrm{T}$ and NK subsets including $\delta 2^{-} \gamma \mathrm{T}$ and memory-like NKG2 $\mathrm{C}^{+} \mathrm{CD} 57^{+} \mathrm{NK}$ cells. Each subset can be further characterized by the expression of 2B4, PD-1, KLRG1, CD45RA, CCR7, CD158, and NKG2A to achieve a fine-tuned mapping of HCMV immune responses. This assay should be useful for the analysis and monitoring of T-and NK cell responses to HCMV infection or vaccines.
\end{abstract}

Keywords: HLA-E; CD8 T cells; NK; $\gamma \delta T ; H C M V ;$ pHLA tetramers; spectral flow cytometry

\section{Introduction}

Human cytomegalovirus (HCMV; human herpesvirus 5, HHV5) is the prototype member of $\beta$-herpesvirus family and a widespread opportunistic pathogen. In healthy individuals, primary infection is subclinical and is followed by a life-long, persistent infection that is controlled by host immune system [1]. However, HCMV is a major cause of morbidity and mortality in immunocompromised individuals such as transplant recipients and patients with HIV infection. Immune response against HCMV is complex, multifactorial, and includes a set of persistent and virus-specific effector NK and CD8 $\alpha \beta \mathrm{T}$ and $\gamma \delta \mathrm{T}$ cell populations [2-4]. These effector cells display cytotoxic functions devoted to eliminating infected cells and preventing further HCMV reactivation [5,6]. HCMV-reactive CD8 $\alpha \beta$ T cells against viral peptides (pp65, IE1, etc.) presented by conventional MHC class I (HLA-A and HLA-B) molecules have been well characterized [7]. These conventional CD8 $\mathrm{T}$ cell responses are usually associated with an efficient control of infection [5]. In addition, CD8 $\mathrm{T}$ cell responses bearing $\alpha \beta \mathrm{TCR}$ but recognizing non-classical $\mathrm{MHC}$, and HLA-E molecules presenting peptides derived from HCMV UL40 protein have emerged as non-conventional T cell responses, also observed in $\mathrm{HCMV}$ seropositif $\left(\mathrm{HCMV}^{+}\right)$hosts including transplant recipients and healthy individuals [8-10]. In a previous study, we have 
detected HLA-E-restricted CD8 T targeting UL40 peptides (HLA-E ${ }_{\mathrm{UL} 40} \mathrm{CD} 8 \mathrm{~T}$ ) in more than $30 \%$ of $\mathrm{HCMV}^{+}$kidney transplant recipients. We have shown that HLA-E $\mathrm{EL} 40_{0} \mathrm{CD} 8 \mathrm{~T}$ cell responses may represent up to $30 \%$ of total blood CD8 T cells in a host post-infection [11].

In contrast to conventional HLA class I-restricted anti-HCMV CD8T cells, the frequency, the peptide-specificity, and the function of HLA-E $\mathrm{EL}_{\mathrm{U} 0} \mathrm{CD} 8 \mathrm{~T}$ cell responses remain mostly unknown [12]. Although the first pieces of knowledge have been reported on the phenotype and functions of HLA-E $\mathrm{UL}_{40} \mathrm{CD} 8 \mathrm{~T}$ cells, a broader characterization of their phenotype in comparison with other, conventional anti-HCMV HLA-I-restricted CD8 T such as HLA-A*02pp65 and HLA-A*02 IE1 cells remains to be established. Concerning their functions, previous studies reported that HLA-E $\mathrm{EL}_{40} \mathrm{CD} 8 \mathrm{~T}$ cells can be activated in vitro and display cytotoxic activity against cellular targets, such as endothelial cells, expressing HLA-E molecules loaded with UL40 peptides [11-13]. The specific implication of anti-HCMV HLA-E $\mathrm{EL}_{40} \mathrm{CD} 8 \mathrm{~T}$ cells to the immune control of HCMV infection is still unknown. It can be speculated that, similar to other HCMV-specific CD8 T cells, HLAE-restricted cytotoxic T cells (CTL) patrol to detect and eliminate infected cells. Another non-exclusive function for HLA-E-restricted CTL could be to ensure the regulation of other anti-HCMV cellular responses such as NK or $\gamma \delta$ T or CD4T cells. Importantly, due to a full sequence homology between the UL40 peptides frequently provided by HCMV strains and some HLA class I peptides, both presented by HLA-E, it has been established that anti-HCMV HLA-E ${ }_{U L 40}$ CD8 T cell responses may cross-react with allogeneic HLA in the setting of solid organ transplantation [11]. Whether this cross-recognition of donor HLA$E_{\text {HLA-I }}$ on allograft could mediate transplant injury and rejection remains to be determined. Nevertheless, the biological relevance of this persistent CD8 T cell subset in the course of HCMV infection and recovery is still unknown.

Detection and analysis of HCMV antigen-specific CD8 T cells require the use of HLA monomers loaded with viral peptides. The interaction between the peptide-HLA (pHLA) complex and a cognate TCR is short lived and of low affinity. By way of multimerization of four peptide-HLA molecules on a streptavidin scaffold, tetramers increase the avidity of the pHLA:TCR interaction by engaging several of the TCRs expressed on a specific $T$ cell, thereby stabilizing the interaction [14]. This allows for direct and specific staining of the T cells. pHLA tetramers provide a simple, fast, and efficient approach for monitoring and handling specific T cells in patients. Peptide-HLA tetramers can be used to identify specific $\mathrm{T}$ cells without further in vitro manipulation, and they allow for a simultaneous evaluation of the differentiation state through co-staining for various cell surface markers for differentiation, activation, and exhaustion [15-17]. Spectral flow cytometry measures the complete emission spectrum to identify fluorochromes. Consequently, in contrast to conventional flow cytometry, spectral flow cytometry is able to differentiate fluorochromes with significant overlap in the emission spectra, enabling the use of spectrally similar fluorochrome pairs in a single assay and thus increasing the number of protein markers that can be analyzed concomitantly $[18,19]$. The present study presents the set up and validation of a method based on the use of a set of HLA- $\mathrm{A}_{\text {peptide }}$ and HLA-E $\mathrm{E}_{\text {peptide }}$ complexes in combination with antibodies for 20 cell markers for the concomitant detection, quantification, and immunophenotyping of non-conventional anti-HCMV HLA-E $\mathrm{UL}_{40}$ CD8 T cells, conventional HLA- $\mathrm{A}^{*} 0201_{\mathrm{pp} 65}$ and other immune responses including NK and $\gamma \delta \mathrm{T}$ cell subsets regulated upon HCMV infection.

\section{Results}

2.1. Quantitative Assessment of CD8 $\alpha \beta T$ Cells in Response to HCMV Infection: CD8 Inflation and Frequencies of Anti-HCMV Peptide-Specific CD8 T Cells

Here, to define our ability to map the various anti-HCMV cellular responses postinfection, we used a combination of three pHLA tetramer complexes (HLA-EVMAPRTLIL, HLA-E VMAPRSLLL, HLA-A2 $_{\text {NLVPMVATV }}$ ) and antibodies for 18 surface markers (CD3, CD4, CD8, CD16, CD19, CD45RA, CD56, CD57, CD158, NKG2A, NKG2C, CCR7, TCR $\gamma \delta$, TCR $\gamma \delta 2, \mathrm{CX} 3 \mathrm{CR} 1, \mathrm{KLRG1}, 2 \mathrm{~B} 4$, and PD-1) in a 20-color multiparameter flow cytome- 
try analysis. For validation, our immunostaining protocol was applied to PBMCs isolated from HCMV- $(n=4)$ and HCMV+ $(n=4)$ individuals and cytometry data were analyzed post-acquisition as follows.

\subsubsection{Lymphocyte Gating}

As an initial gating strategy to discriminate anti-HCMV NK and T cell populations (Figure 1), both forward and side scatter (FSC-Area (A) vs. FSC-Height (H) and SSC-H vs. SSC-A) dot plots were used to exclude doublets and to target singlets only (Figure 1A). Next, FSC vs. SSC gating was used to identify lymphocytes based on size and granularity. It is often suggested that forward scatter indicates cell size, whereas side scatter relates to the complexity or granularity of the cell. This gating strategy is also used to exclude debris, as they tend to have lower forward scatter levels. They are found at the bottom left corner of the FSC vs. SSC density plot. Next, live cells were selected using Fixable Viability Stain 440UV as a viability marker. This dye reacts with and covalently binds to cell-surface and intracellular amines. Permeable plasma cell membranes, such as those present in necrotic cells, allow for the intracellular diffusion of the dye and covalent binding to higher overall concentrations of amines than in non-permeable live cells. Using the expression for CD3 and $\gamma \delta \mathrm{TCR}$ allows us to determine three lymphocyte subsets: CD3 ${ }^{-}$ $\gamma \delta \mathrm{TCR}{ }^{-}$cells including mostly B lymphocytes and NK cells, $\mathrm{CD}^{+} \gamma \delta \mathrm{TCR}^{-}$cells including mostly $\alpha \beta$ TCR T cells, and finally, $\mathrm{CD}^{+} \gamma \delta \mathrm{TCR}^{+}$cells, which include $\gamma \delta \mathrm{T}$ cells (Figure $1 \mathrm{~A}$ ). Thus CD3/ $\gamma \delta$ TCR costaining provides the distribution of these three subsets among PBMC samples issued from $\mathrm{HCMV}^{+}$patients and controls and may be indicative of $\gamma \delta \mathrm{TCR}$ inflation post-infection.

\subsubsection{CD4/CD8 Ratio}

CD4 and CD8 expression was then examined in the $\mathrm{CD}^{+} \gamma \delta \mathrm{TCR}^{-}$lymphocyte population to define the percentage of $\mathrm{CD}^{+} \mathrm{T}$ cells, $\mathrm{CD} 8^{+} \mathrm{T}$ cells as well as double positive and negative $\mathrm{CD}^{+} \mathrm{T}$ cells (Figure $1 \mathrm{~B}$ ). As illustrated in Figure 1C, our data show that HCMVindividuals display a higher percentage of CD4 compared to CD8 (mean values: 66.6\% vs. $33.4 \%$ for CD4 and CD8 T cells, respectively, from HCMV-individuals $(n=4), p<0.05)$. In contrast, $\mathrm{HCMV}^{+}$individuals, even at a distance from primary infection, display no significant difference in the percentages of CD4 versus CD8 T cells (mean values: $48.9 \%$ vs. $51.1 \%$ for CD4 and CD8 T cells, respectively, from four $\mathrm{HCMV}^{+}$individuals), indicative of an HCMV-induced CD8 T cell inflation. Indeed, expansion of the CD8 T cell pool occurs early post-infection and is a hallmark of HCMV and HIV infections [20-22].

\subsubsection{HCMV Peptide-Specific CD8 T Cell Responses}

Three pHLA tetramer complexes were used in conjunction with anti-CD8 antibodies for the immunostaining of conventional and unconventional HCMV peptide-specific CD8 $\mathrm{T}$ cell responses. Conventional CD8 T cells were detected using HLA-A*0201(A2)/pp65 (NLVPMVATV) tetramer complexes, while unconventional HLA-E restricted CD8 T cells were detected using two HLA-E tetramer complexes containing two different UL40 signal peptides (HLA-E/VMAPRTLIL and HLA-E/VMAPRSLLL). Examples of detection using HLA$\mathrm{A} 2_{\text {pp65 }}$ and HLA-E $\mathrm{EL}_{40}$ tetramers and CD8 costaining are shown in Figure 1D,E and reveal similar frequency (from 2 to $6 \%$ of total CD8 T cells) for both HCMV antigen-specific, HLA-A2 $2_{\text {pp65 }}$ and HLA-E ${ }_{U L 40}$, CD8 T cells, consistent with our previous studies [11] Thus, CD8/HLA classI/peptide tetramer costaining allows the detection and quantification of HCMV-specific conventional but also unconventional, HLA-E-restricted CD8 T cell populations using spectral flow cytometry.

\subsection{Immunophenotyping of CD8 T Cell Responses}

2.2.1. CD8 T Cell Differentiation

HCMV peptide-specific CD8 T cells stained with pMHC class I tetramers can be further characterized by immunophenotyping using antibodies for CD45RA, CCR7, CX3CR1, 
PD-1, CD56, CD57, CD158, NKG2A, NKG2C, KLRG1, and 2B4. Firstly, costaining for CD45RA and CCR7 allows us to segregate CD8 $\mathrm{T}$ cells according to their differentiation state: CD45RA ${ }^{+} \mathrm{CCR}^{+} \mathrm{CD} 8 \mathrm{~T}$ cells are defined as naive T cells (TN), CD45RA ${ }^{-} \mathrm{CCR}^{-}$ as central memory $\mathrm{T}$ cells (TCM), CD45RA ${ }^{-} \mathrm{CCR7}^{+}$as effector memory T cells (TEM),

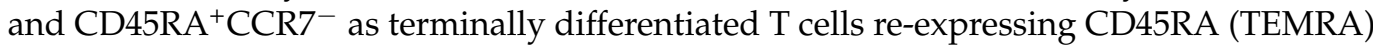
(Figure 2A) [23]. Consequently, CD45RA/CCR7 costaining enables a comparative analysis of CD8 T cell differentiation for HCMV peptide-specific CD8 T cells stained with pHLA class I tetramers, such as conventional vs. unconventional (HLA-E-restricted) CD8 T and a comparison between HCMV peptide-specific CD8 T cells and total (tetramer negative) CD8 T cell pool (Figure 2A). As illustrated in Figure 2A lower panel, and consistent with previous studies [22,23], a majority of CD8 $\mathrm{T}$ cells (around 70\%) in $\mathrm{HCMV}^{+}$individuals are TEMRA cells expressing CD45RA but not CCR7. Considering HCMV-specific responses, only a part of HLA-A2 $2_{\text {pp65 }}$ and almost all anti-HCMV HLA-EUL40 CD8 T cells stained with HLA-E ${ }_{\mathrm{UL} 40}$ tetramers that persist in $\mathrm{HCMV}^{+}$individuals post-infection display a CD45RA ${ }^{+}$ $\mathrm{CCR7}^{-}$phenotype and thus belong to TEMRA cells (Figure 2A). Figure 2B provides a quantification of the CD8 differentiation stages in $\mathrm{HCMV}^{+}$versus $\mathrm{HCMV}^{-}$individuals, indicating a trend toward less TN and more TEMRA in $\mathrm{HCMV}^{+}$individuals, which may reflect the impact of HCMV-specific CD8 populations, as previously reported [22,24].
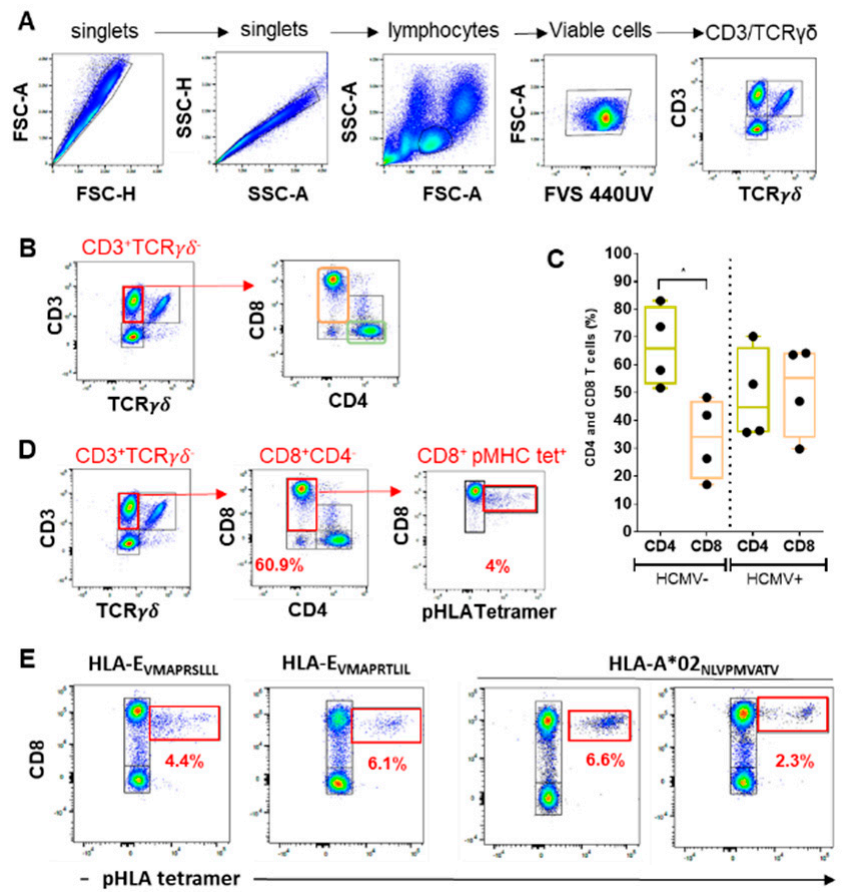

Figure 1. (A) A representative nested gating strategy illustrating lymphocyte population subgated by the expression of CD3 and $\gamma \delta$ TCR. Cells were gated first on FSC-A vs. FSC-H plots and then on SSC-H vs. SSC-A plots to eliminate doublets. Lymphocytes were gated on an SSC-A vs. FSC-A dot plot. Viable lymphocytes were selected using fixable viability stain (FVS) 440UV staining. Lymphocytes were subgated using CD3 and $\gamma \delta \mathrm{TCR}$ staining. $(\mathbf{B}, \mathbf{C})$ Analysis of CD4 and CD 8 lymphocyte subsets. A representative density plot showing CD4 and CD8 staining among the CD3 ${ }^{+} \gamma \delta \mathrm{TCR}$ - lymphocytes. (C) A graphical and statistical analysis of CD4 and CD8 lymphocyte subsets from independent $\mathrm{HCMV}^{-}(n=4)$ and $\mathrm{HCMV}^{+}(n=4)$ individuals. (D,E) Detection and quantification of peptidespecific conventional and non-conventional CD8 T cell populations using HLA class I /peptide tetramers (pHLA). Representative detection of anti-HCMV peptide-specific, conventional (HLAA2 2 p65, peptide NLVPMVATV) and two unconventional (HLA-EUL40, peptides VMAPRSLLL and VMAPRTLIL), CD8 T cells from three $\mathrm{HCMV}^{+}$hosts is shown. The percentages of tetramer positive cells (tet+) among total CD8 T cells are indicated. FSC-H: Forward scatter height. FSC-A: Forward scatter area. SSC: Side scatter. TCR: T cell receptor. $p$ value: * for $p<0.05$. 

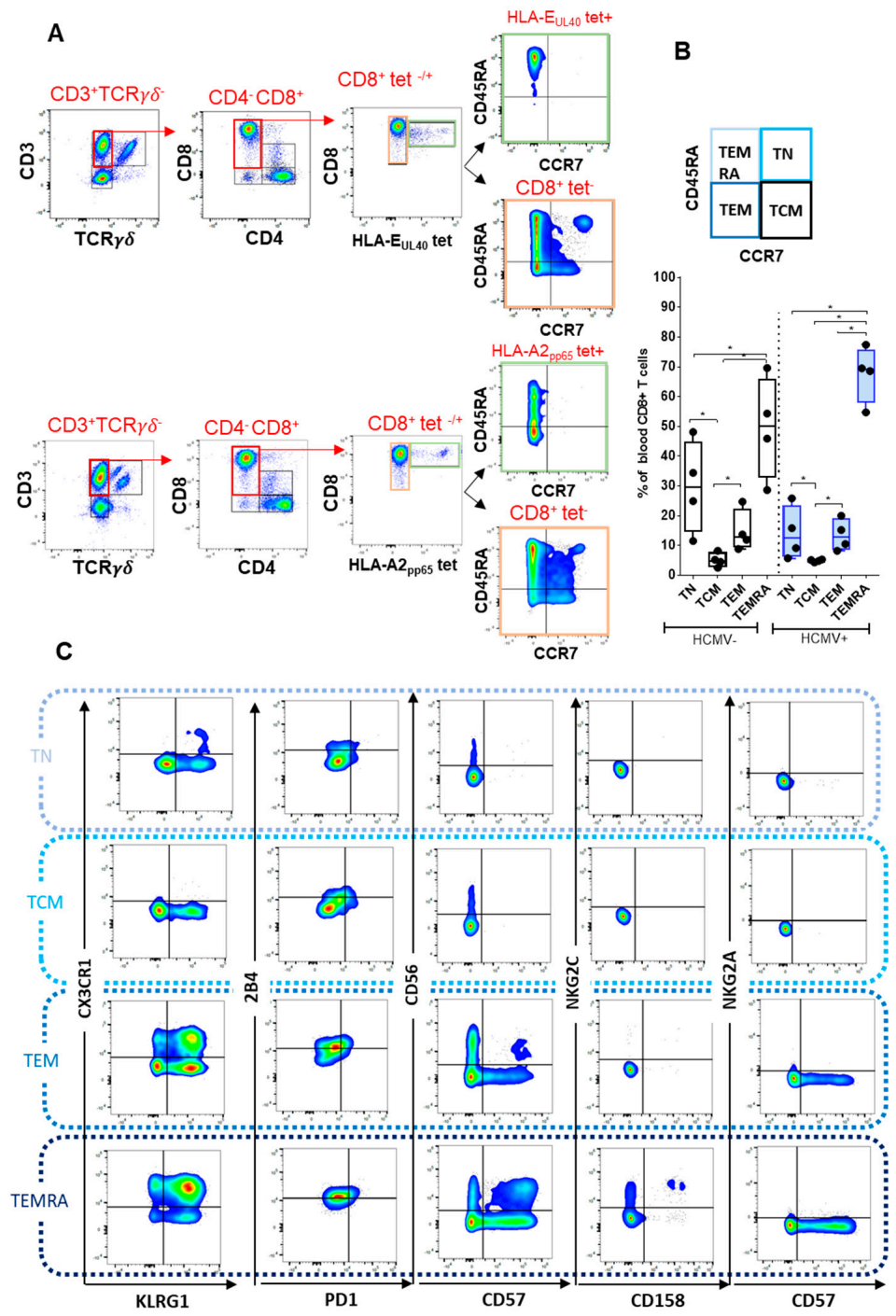

Figure 2. Analysis of CD8 T cell differentiation. (A) Representative density plots showing the sequential gating of CD8 T cells negatively (tet-) and positively (tet+) stained by pMHC class I tetramer (HLA-E $\mathrm{EL}_{40}$ VMAPTSLLL, upper panel or HLA-A2 ${ }_{\mathrm{pp} 65}$, lower panel) after a selection according to $\mathrm{CD} 4$ and CD8 costaining among the $\mathrm{CD} 3^{+} \mathrm{TCR} \gamma \delta^{-}$lymphocytes. The expression pattern for CD45RA/CCR7 of each population (tet ${ }^{-}$and tet ${ }_{+}$) is shown. (B) A schematic representation of CD8 differentiation stages including CD8 naive T cells (TN), central memory T cells (TCM), effector memory T cells (TEM), and terminally differentiated T cells (TEMRA) according to CD45RA and CCR7 expression is indicated (upper panel). A graphical and statistical analysis of differentiation for total CD8 T cell pool from independent $\mathrm{HCMV}^{-}(\mathrm{n}=4)$ and $\mathrm{HCMV}^{+}(n=4)$ individuals. Data are expressed as box plot with median and interquartile values. (C) Immunophenotyping of CD8 T cells for receptors for $\mathrm{T}$ cell activation and inhibition (2B4, PD-1, CD158, NKG2A, NKG2C, KLRG1), migration (CX3CR1) and cytotoxic capacity (CD56, CD57). The coexpression of receptors are shown for the 4 differentiation states (TN, TCM, TEM, TEMRA) analyzed for total CD8 T cells and representative of a single HCMV+ individual. $p$ value: * for $p<0.05$.

2.2.2. Immunophenotyping of Naive, Central Memory, Effector Memory, and Terminally Differentiated CD8 ${ }^{+} \mathrm{T}$ Cell Subsets

Concomitant costaining with a panel of antibodies was performed to investigate, in a single assay, receptors for T cell activation and inhibition (2B4, PD-1, CD158, NKG2A, NKG2C, and KLRG1), migration (CX3CR1), and cytotoxic and proliferation capacity (CD56, CD57). This antibody panel was used to better characterize and to compare the various $\mathrm{T}$ cell subsets according to their differentiation state, as illustrated in Figure 2C. CD8 T cell 
differentiation from TN to TEMRA is associated with gain and loss of expression for several receptors, as previously reported [23]. Upon differentiation, CD8 T cells acquire both CX3CR1 and the inhibiting receptor KLRG1, which are not expressed on TN but appear on TEM and are coexpressed (80\% of cells) on TEMRA. Similarly, the expression of the activating receptor $2 \mathrm{~B} 4$ progress along differentiation with majority of TEMRA (55\%) being 2B4 ${ }^{+}$. NKG2C and CD158 are expressed or even coexpressed on TEMRA only. Concerning cytotoxic activity, the expression of CD56 is null for CD8 TN and TCM, appears maximal for TEM (18.2\%), and then decreases for TEMRA $(5.2 \%)$, while CD57 appears on TEM $(13.7 \%)$ and further increases for TEMRA (27.8\%). TEM and TEMRA, coexpressing both CD56 and CD57, represent $2.4 \%$ and $12.0 \%$, respectively. Only a small portion of CD8 TEMRA express the activating receptor NKG2C (4.84\%, and among them, $1.39 \%$ coexpress CD158). These data indicate that our workflow is robust enough to provide an accurate phenotype comparison across the four differentiation stages of CD8 T cells, thus enabling us to characterize HCMV-specific CD8 T cell subsets.

\subsection{Deciphering $\gamma \delta T$ and $V \delta 2^{-} \gamma \delta T$ Cells upon HCMV Infection}

The $\gamma \delta$ T cells are an integral part of the immune response against HCMV [6,25]. Using our protocol, the use of anti- $\gamma \delta \mathrm{TCR}$ antibodies allows the positive selection of lymphocytes expressing both CD3 and an $\gamma \delta \mathrm{TCR}$, thus excluding conventional CD3 ${ }^{+} \mathrm{T}$ lymphocytes that bear conventional $\alpha \beta$ TCR (Figure 3A). This gating step provides a quantification for total $\gamma \delta \mathrm{T}$ cells in blood samples from $\mathrm{HCMV}^{-}$and $\mathrm{HCMV}^{+}$hosts (Figure 3A,B). Consistent with previous studies [6], $\gamma \delta \mathrm{T}$ cells comprise around $10 \pm 7 \%$ of total $\mathrm{CD}^{+}$cells in both $\mathrm{HCMV}^{-}$and $\mathrm{HCMV}^{+}$individuals (Figure 3B). In a subsequent step, subgating of $\mathrm{CD}^{+}$ $\gamma \delta \mathrm{T}$ according to the expression of $\delta 2 \mathrm{TCR}$ chain and CD8 provided a mean to focus on $\mathrm{CD}^{+} \gamma \mathrm{V} \delta 2^{-} \gamma \delta \mathrm{T}$ cells. In humans, $\gamma \delta \mathrm{T}$ cells are divided in two subsets, the $\mathrm{V} \gamma 9^{+} \mathrm{V} \delta 2^{+} \mathrm{T}$ cells that are found predominantly in the blood and all the other $\gamma \delta$ T cells (collectively called $\mathrm{V} \delta 2^{-} \gamma \delta \mathrm{T}$ cells, and mainly composed of $\mathrm{V} \delta 1^{+}$and $\mathrm{V} \delta 3^{+} \mathrm{T}$ cells) that are primarily located in tissues, particularly in epithelia [6]. HCMV infection leads to a strong increase (in proportion and number) in $\gamma \delta$ T cell subsets in the blood circulation, which persisted long term [26]. HCMV induces the expansion of $V \delta 2^{-} \gamma \delta \mathrm{T}$ cells in the blood, which correlates with the resolution of infection providing evidence for an antiviral function of these subset of $\gamma \delta \mathrm{T}$ cells $[27,28]$. Our data illustrate the predominance of $\mathrm{V} \delta 2^{-} \gamma \delta \mathrm{T}$ cells over $\mathrm{V} \delta 2^{+} \gamma \delta$ $\mathrm{T}$ cells in $\mathrm{HCMV}^{+}$hosts with a frequency that ranges between $38 \%$ and $97 \%$ (mean value: $65.6 \%$ ) of total $\mathrm{CD}^{+} \gamma \delta \mathrm{T}$ cells but with large individual variations (Figure 3C). HCMVinduced $\gamma \delta$ T cells mostly express an effector/memory TEMRA phenotype (Figure 3A) with similarities to the one described for HCMV-specific $\mathrm{CD}^{+} \alpha \beta$ T cells [23]. Subgating on CD45RA/CCR7 indicated divergent differentiation status for $\mathrm{V} \delta 2^{-} \gamma \delta \mathrm{T}$ cells vs. $\mathrm{V} \delta 2^{+} \gamma \delta \mathrm{T}$ cells with almost all $\mathrm{V} \delta 2^{-} \gamma \delta \mathrm{T}$ beeing TEMRA $\left(\mathrm{CD}^{-} 5 \mathrm{RA}^{+} \mathrm{CCR} 7^{-}\right)$, whereas $\mathrm{V} \delta 2^{+} \gamma \delta \mathrm{T}$ cells include mostly less-differentiated $\mathrm{T}$ cells in $\mathrm{HCMV}^{+}$individuals. To further characterize HCMV-induced $\gamma \delta \mathrm{T}$ cells, the phenotype of both subsets was investigated for the immune receptors used for phenotyping CD8 $\alpha \beta$ T cells. Comparison of expression pattern further highlights phenotype differences between $\mathrm{V} \delta 2^{-}$and $\mathrm{V} \delta 2^{+} \gamma \delta \mathrm{T}$ cells and suggests that coexpression for CX3CR1 and KLRG1 and CD56/CD16 expression featured V $\delta 2^{-} \gamma \delta \mathrm{T}$ cells (Figure 3A).

\subsection{Analysis of HCMV-Induced NK Cell Subsets}

In healthy human adults, NK cells comprise $5-15 \%$ of circulating lymphocytes; together with T cells and B cells, they are one of the three major lymphoid lineages [29]. Within lymphocytes, NK cells are phenotypically defined as CD56 ${ }^{+}$cells that do not express T (CD3) or B (CD19) cell lineage markers. In our protocol, sequential gating on $\mathrm{CD}^{-} \mathrm{TCR}^{-} \delta$ - cells followed by the exclusion of $\mathrm{CD}_{19}{ }^{+}$cells allowed us to define $\mathrm{CD}^{-}{ }^{-} \mathrm{CD} 19^{-} \mathrm{CD} 56^{+/-}$ as NK cells (Figure 4A,B). Accordingly, the total percentages of NK cells among peripheral lymphocytes were calculated in samples from $\mathrm{HCMV}^{-}$and $\mathrm{HCMV}^{+}$individuals and are shown in (Figure 4C). The expression of CD56 in combination with CD16, the low- 
affinity Fc $\gamma$ receptor IIIa, further allows to distinguish different NK cell subsets [30,31]. By examining CD56 and CD16 costaining, we were able to identify NK cells at different stages of differentiation, including the immature $\mathrm{CD} 56^{-} / \mathrm{CD}^{-} 6^{-}$, the early differentiated

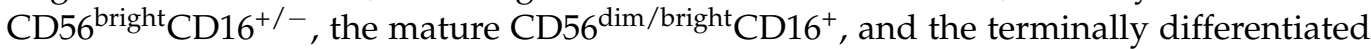
$\mathrm{CD}^{-} 6^{-} \mathrm{CD} 16^{+} \mathrm{NK}$ cell subsets $[32,33]$. When comparing the frequency of each subset in $\mathrm{HCMV}^{-}$and $\mathrm{HCMV}^{+}$individuals, we found that $\mathrm{CD} 56^{\mathrm{dim}} \mathrm{CD} 16^{+}$respresent the vast majority of NK cells in both groups (Figure 4D). HCMV infection triggers the specific expansion of mature $\mathrm{CD} 56^{\mathrm{dim}} \mathrm{CD} 16^{+} \mathrm{NK}$, expressing the $\mathrm{CD} 94 / \mathrm{NKG} 2 \mathrm{C}$ activating receptor and coexpressing the CD57 with a high cytotoxic activity. Thus, subgating using CD57 and NKG2C markers was performed for all the samples to calculate the percentages of mature $\mathrm{CD}^{2}{ }^{\mathrm{dim}} \mathrm{CD} 16^{+} \mathrm{CD} 57^{+} \mathrm{NKG} 2 \mathrm{C}+$ in $\mathrm{HCMV}^{-}$and $\mathrm{HCMV}^{+}$hosts, as shown in Figure 4E. Our data indicated that, although no statistically significant difference was achieved due to individual variability, the frequency of mature, memory-like CD56 ${ }^{\mathrm{dim}} \mathrm{CD} 16^{+} \mathrm{CD} 57^{+}$ $\mathrm{NKG}_{2} \mathrm{C}^{+}$appears higher in $\mathrm{HCMV}^{+}$compared to $\mathrm{HCMV}^{-}$hosts.

A

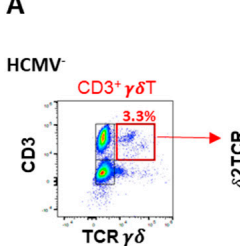

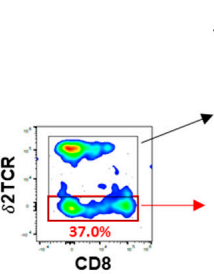
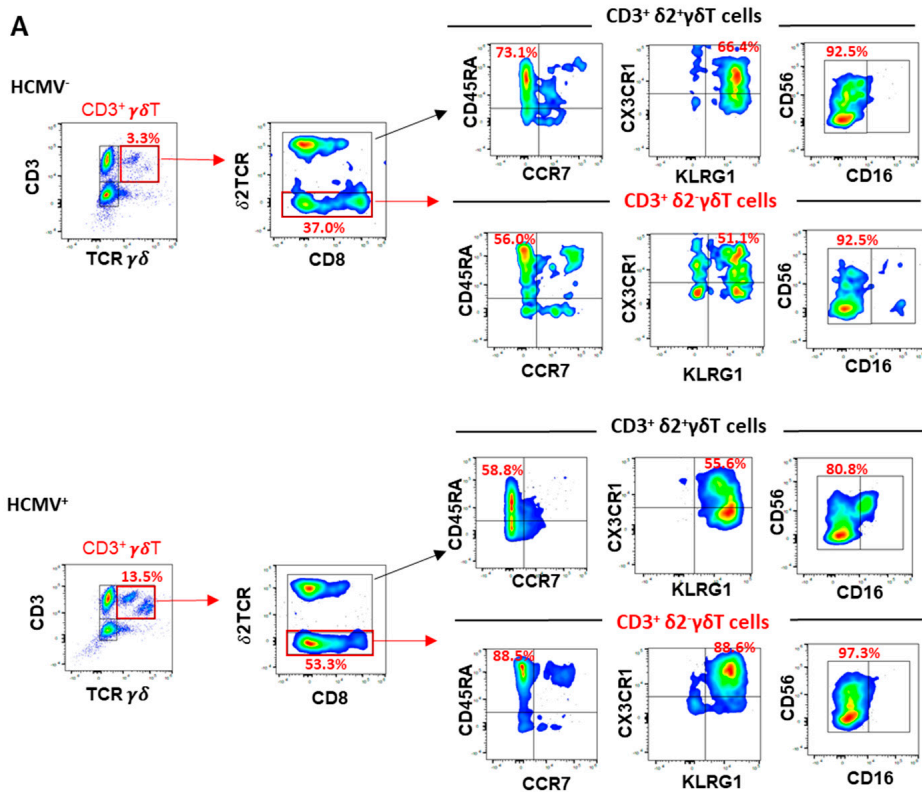

$\mathrm{CD}^{+} \delta 2^{+} \gamma \delta \mathrm{T}$ cells

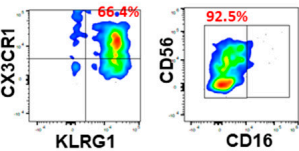

KLRG1

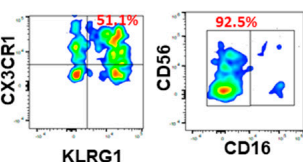

CD16

CD16
B

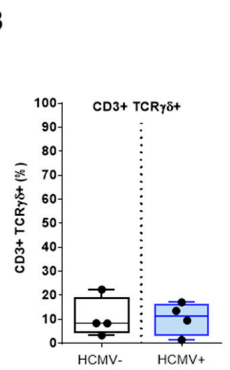

C

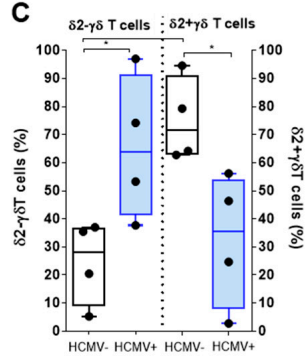

Figure 3. Analysis of $\gamma \delta \mathrm{T}$ and $\mathbf{V} \delta 2^{-} \gamma \delta \mathrm{T}$ cells. (A) Representative density plots from a single $\mathrm{HCMV}^{-}$(upper panel) and $\mathrm{HCMV}^{+}$(lower panel) individuals showing the sequential selection of $\mathrm{CD}^{+} \gamma \delta \mathrm{T}$ cells using CD 3 and $\gamma \delta \mathrm{TCR}$ costaining and of $\mathrm{V} \delta 2^{-} \gamma \delta \mathrm{T}$ and $\mathrm{V} \delta 2^{+} \gamma \delta \mathrm{T}$ subsets using $\mathrm{V} \delta 2 \gamma \delta \mathrm{T}$ and CD 8 costaining used to quantify the $\gamma \delta \mathrm{T}$ cell subsets. Immunophenotyping of $\gamma \delta \mathrm{T}$ cell subsets showing costaining for CD45RA/CCR7, CX3CR1/KLRG1 and CD56/CD16. The coexpression of immune receptors for $\mathrm{V} \delta 2^{-} \gamma \delta \mathrm{T}$ vs. $\mathrm{V} \delta 2^{+} \gamma \delta \mathrm{T}$ cell populations are shown. For comparison, cell frequency $(\%)$ is indicated for some costainings. $(\mathbf{B}, \mathbf{C})$ Box plots with median and interquartile values were used to represent the percentages of (B) $\mathrm{CD}^{+} \gamma \delta^{+} \mathrm{T}$ among lymphocytes and (C) V $\delta 2^{-} \gamma \delta \mathrm{T}$ vs. $\mathrm{V} \delta 2^{+} \gamma \delta \mathrm{T}$ cells obtained from independent $\operatorname{HCMV}^{-}(n=4)$ and $\operatorname{HCMV}^{+}(n=4)$ individuals. $p$ value: * for $p<0.05$. 


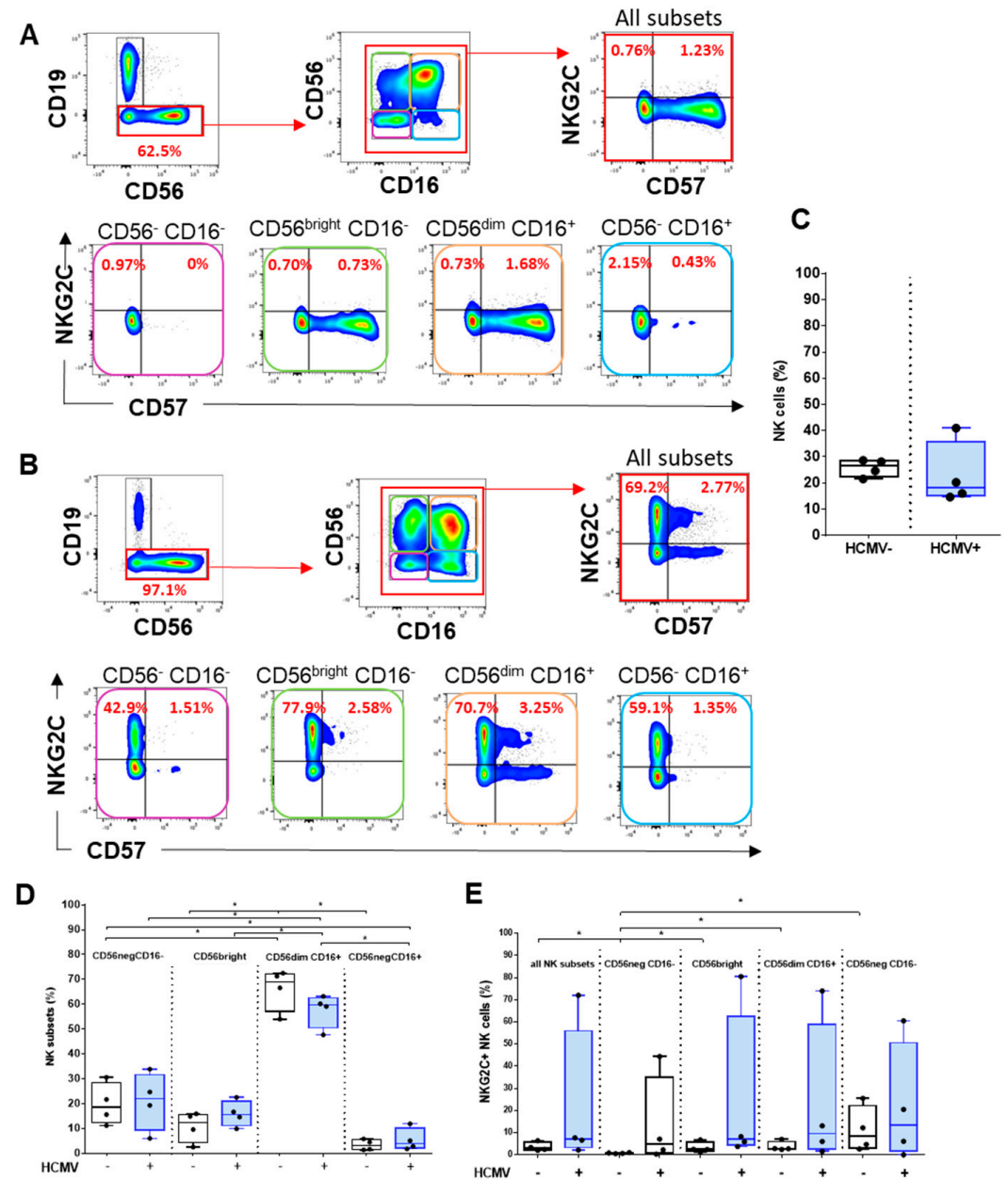

Figure 4. Analysis of HCMV-induced NK cell subsets. (A,B) Representative density plots showing the sequential selection (upper panel, left to right) CD3- $\gamma \delta^{-} \mathrm{T}$ cells, CD19- cells using CD19/CD56 costaining, and CD56/CD16 costaining, enabling the determination of 4 major NK cell subsets. Co-expression for CD57/NKG2C is shown for all NK (upper panel) and for each NK subset (lower panel). The data shown are from one representative $\mathrm{HCMV}^{-} \mathrm{HV}(\mathbf{A})$ and $\mathrm{HCMV}^{+}$kidney transplant recipient (B). For comparison, cell frequency (\%) is indicated for some costainings. Quantitative analyses are represented as box plots comparing the percentages of total NK cells (C), the percentages of NK subsets (D), and the percentages of NKG2C+ $\mathrm{NK}$ cells $(\mathbf{E})$ for $\mathrm{HCMV}^{-}(n=4)$ and $\mathrm{HCMV}^{+}$ $(n=4)$ individuals. $p$ value: ${ }^{*}$ for $p<0.05$.

\section{Discussion}

Flow cytometry provides a high-throughput and cost-effective method of immunophenotyping and immunomonitoring of patients (currently, more than 40 fluorophores are available) on many cells with high-throughput (approx. 10,000 events/s). In contrast to flow cytometry, which uses fluorescent molecules, mass cytometry uses heavy metal tags and time-of-flight mass spectrometry readouts to measure antibody binding to cells [34]. This method allows a much larger number of simultaneous markers than conventional flow cytometry. Mass cytometry, on the other hand, acquires cells at a much lower rate (approx. 300-400 events/s) but with more markers per cell (over 50). Spectral cytometry improves conventional flow cytometry by increasing the number and combination of fluorophores, thereby providing increased flexibility of panel design, as well as incorporating autofluorescence measurement and extraction [19]. By the use of fluorophore-conjugated antibodies, staining, and analysis protocols already established for conventional cytometry, spectral cytometry provides a readily accessible technique [35]. 
Here, we report on the development of a staining protocol and a staining strategy combining HLA class I/HCMV peptides tetramer complexes and a panel of 18 antibodies to study HCMV-specific immune cell responses. HLA/peptide tetramer staining offers the possibility to detect and quantitate peptide-specific anti-HCMV CD8 T cell populations [16]. The tetramers that we used include HLA-A2pp65 tetramers and HLA-E $\mathrm{E}_{\mathrm{UL} 40}$ tetramers to decipher HLA-E-restricted CD8 T cells induced in the response to HCMV infection. It is important to emphasize that HLA-E $\mathrm{EL}_{40}$ tetramers bind to both NK and T cells. HLA-E is a ligand for the heterodimeric CD94/NKG2A/C receptors [36], which are expressed at high level on NK cells and are also expressed at lower level on CD8 T cells [36,37]. To allow a TCR-specific binding and to avoid the binding of HLA-E $\mathrm{EL}_{40}$ tetramers to CD94/NKG2A and CD94/NKG2C receptors, we performed a CD94 blockade using blocking antibodies as a preliminary step of immunostaining as we previously reported [11,13]. A major result from this study was the efficient detection of both HLA-A2 $2_{\mathrm{pp} 65}$ and HLA-E $\mathrm{EL}_{40}$ CD8 T cells stained with the tetramers in our experimental conditions using spectral cytometry. In the present study, we found that the frequency of pp65 and UL40 epitope-specific T cells among CD8 T cells was in the range of the frequency that we previously reported with conventional flow cytometry [11]. This result indicates that the binding of pHLA tetramer remains stable during the processes of immunostaining and data acquisition and is strong enough to allow cell detection by spectral flow cytometry. Therefore, pHLA-E tetramers against UL40 HCMV epitopes combined with cell surface markers allow us to study these HCMV-specific CD8 T cell responses in more detail in a large cohort of patients. Previous studies established the emergence of HLA-E-restricted CD8 T cell subsets in autoimmune [38] and infectious diseases [12,39]. Functionally, in some studies, HLA-Erestricted CD8 T cells have been shown to display cytotoxic activities $[8,11,39]$ toward autologous, allogeneic, or infected cells expressing HLA-E such as endothelial cells [40] but also regulatory functions [38], as reported in mice [41]. The role of HLA-E-restricted CD8 T cells in the outcome on HCMV infection is still unknown. Previous analysis of phenotype identified HCMV-specific HLA-E CD8 T as terminally differentiated TEMRA cells expressing CD56 $[8,11]$. Commonly, there is no known specific surface receptor that leads to HLA- $\mathrm{E}_{\mathrm{UL} 40} \mathrm{CD} 8 \mathrm{~T}$ cell identification within PBMCs that may help to analyze or sort these T cells without using HLA-E tetramers. The phenotypic and molecular characteristics of these CD8+ T cells therefore require further study. To investigate further the role that HLA-E $\mathrm{EL}_{40} \mathrm{CD} 8 \mathrm{~T}$ cells may play in the control of HCMV infection, we sought to set up an integrated analysis of the multiple cellular responses induced by the infection. Our panel of antibodies enables the concomitant determination in a single sample of the frequency for a set of anti-HCMV responses such as conventional and unconventional peptide-specific CD8 T cells, total $\gamma \delta \mathrm{T}$ and $\delta 2^{-} \gamma \mathrm{T}$ cells, immature and mature NK, and memory-like NK cells expressing NKG2C and/or CD57 [6,42]. Each subset can be further characterized for the expression of several markers including 2B4, PD-1, KLRG1, CD45RA, CCR7, CD158, and NKG2A to achieve a fine-tuned analysis of HCMV immune responses. Future applications for this assay include a better knowledge of HCMV infection through the comprehensive analysis of NK and T cell responses to HCMV infection or vaccines and a tool for the stratification of transplanted patients according to risk factors related to HCMV infection [43,44].

\section{Materials and Methods}

\subsection{Samples and Reagents}

Blood samples collected from seronegative $\left(\mathrm{HCMV}^{-}\right)$and seropositive $\left(\mathrm{HCMV}^{+}\right)$ anonymous healthy volunteers (HV) were obtained from the Etablissement Français du Sang (EFS des Pays de La Loire, Nantes, France) with donors' specific and written informed consent for research use. PBMCs were isolated by Ficoll density gradient (Eurobio, Les Ulis, France) and keep frozen until used. Banked biological samples (PBMCs) from $\mathrm{HCMV}^{+}$ kidney transplant recipients were issued from the DIVAT biocollection (CNIL agreement $\mathrm{n}^{\circ}$ 891735, French Health Minister Project $\mathrm{n}^{\circ}$ 02G55). PBMCs from patients who underwent 
kidney transplantation in the Institute for Transplantation Urology Nephrology (ITUN, CHU de Nantes, France) were prospectively isolated from blood samples, frozen, and stored at the Centre de Ressources Biologiques (CRB, CHU de Nantes, France). PBMCs were thawed before use in RPMI-1640 medium (Gibco, Amarillo, TX, USA) supplemented with 10\% human serum (Gibco), 2 mM L-glutamine (Gibco), $100 \mathrm{U} / \mathrm{mL}$ penicillin (Gibco), and $0.1 \mathrm{mg} / \mathrm{mL}$ streptomycin (Gibco). To set up the present protocol, we used blood samples that we previously tested for the absence or the presence of HCMV peptidespecific CD8 T cells using a set of pHLA tetramers and conventional flow cytometry. Four PBMC samples containing different HCMV peptide-specific CD8 T cells were then selected for the study. These 4 samples were issued from $2 \mathrm{HCMV}^{+}$healthy donors and from 2 $\mathrm{HCMV}^{+}$kidney transplant recipients. The two groups included $2 \mathrm{~F} / 2 \mathrm{M}$ and $1 \mathrm{~F} / 3 \mathrm{M}$ for $\mathrm{HCMV}^{-}$and HCMV+ individuals, respectively. The mean values of ages are $47.5 \pm 14.7$ and $55 \pm 14.7$ years for $\mathrm{HCMV}^{-}$and $\mathrm{HCMV}^{+}$, respectively, and thus are not significantly different.

\subsection{HLA-E $E_{U L 40}$ and HLA-A*02:01 ${ }_{p p 65}$ Tetramer Complexes}

Peptides from HCMV UL40 protein $\left(\mathrm{AA}_{15-23}\right.$ : VMAPRTLIL and VMAPRSLLL) and

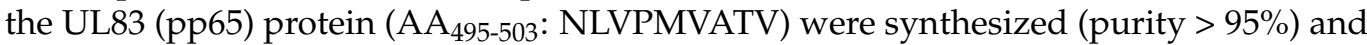
purchased from Genecust (Boynes, France). The HLA peptide $_{\text {monomers HLA-E*01:01 }}$ UL40 and HLA-A*02:01 ${ }_{\text {pp } 65}$ were produced by the recombinant protein core facilities (P2R, SFR Bonamy, Université de Nantes, France) as we previously reported [11]. HLA peptide monomers were biotinylated, purified, and tetramerized using APC-streptavidin (BD Biosciences, Le Pont de Claix, France).

\subsection{Spectral Flow Cytometry: Immunostaining, Acquisition and Post-Acquisition Data Analysis}

The 20-marker panel was optimized for use on a Cytek Aurora (Cytek Biosciences, Fremont, CA, USA) spectral flow cytometry platform with a 5-laser configuration (laser excitation wavelengths: $355 \mathrm{~nm}, 405 \mathrm{~nm}, 488 \mathrm{~nm}, 561 \mathrm{~nm}$, and $640 \mathrm{~nm}$ ). Before use, titration experiments were carried out to determine the antibody concentration providing highest staining index. For immunophenotyping, cells (1.106 PBMCs/well in 96-well plates) were costained using a multistep protocol. PBMCs were washed twice in RPMI and cells and filtered through a $100 \mu \mathrm{m}$ filter (ThermoFisher, Waltham, MA USA) before immunostaining. PBMCs were then incubated with a viability marker, Fixable Viability Stain 440UV (BD Bioscience) and diluted in PBS $(100 \mu \mathrm{L})$ for 15 min at $4{ }^{\circ} \mathrm{C}$. PBMCs were washed twice in PBS and centrifugated at $2500 \mathrm{rpm}$ for $2 \mathrm{~min}$ at $4{ }^{\circ} \mathrm{C}$. Next, cells were incubated with antiNKG2A (Biotechne, Noyal-Châtillon-sur-Seiche, France) and anti-NKG2C (BD Bioscience) mAbs for $15 \mathrm{~min}$ at $4{ }^{\circ} \mathrm{C}$, diluted in PBS $(30 \mu \mathrm{L})$ before being incubated in PBS $(30 \mu \mathrm{L})$ for $25 \mathrm{~min}$ at $4{ }^{\circ} \mathrm{C}$ with blocking anti-CD94 $\mathrm{mAb}$ (BD Bioscience) to avoid the binding of

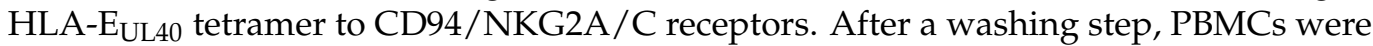
incubated with APC-labeled -HLA peptide tetramers $(50 \mu \mathrm{g} / \mathrm{mL}$ in $30 \mu \mathrm{L}$ PBS) for 20 min at RT. After washing, PBMCs were incubated successively for $10 \mathrm{~min}$ at $4{ }^{\circ} \mathrm{C}$ with 5 cocktails of antibodies diluted in PBS $(30 \mu \mathrm{L})$ : cocktail 1 containing Fc-block ${ }^{\mathrm{TM}}$ reagent (BD Bioscience) and anti-CCR7, cocktail 2 containing anti-TCR $\gamma \delta$ and anti-TCR $\gamma \delta 2$, cocktail 3 containing antiCX3CR1 mAbs alone, cocktail 4 containing anti-CD158, -KLRG1, -2B4, -PD-1 mAbs, and cocktail 5 containing anti- CD4, -CD57, -CD3, -CD45RA, -CD8, -CD56 and -CD16 mAbs. After a washing step, PBMCs were finally incubated with anti-CD19 mAbs for $15 \mathrm{~min}$ at $4{ }^{\circ} \mathrm{C}$. All antibodies are listed in Table 1. PBMCs were washed twice and were resuspended in PBS before fluorescence analysis. For our study, a mean value of 40,000 events (viable lymphocytes)/samples were acquired for analysis. The fluorescence intensities were measured with a five-laser Cytek Aurora ${ }^{\mathrm{TM}}$ spectral flow cytometer (Cytek Biosciences) using SpectroFlo ${ }^{\mathrm{TM}}$ software version 2.2.0 (Cytek Biosciences). Using online fluorescence spectra viewers, we were able to identify 20 fluorophores with distinct signatures that could be used in the panel. The selected fluorophores included BUV395, UV440, BUV496, BUV563, BUV737, BUV805, BV421, VioBlue, BV510, BV570, BV605, BV785, FITC, PerCPeFluor710, PE, AlexaFluor594, 
PE-Cy7, SparkNir685, APC Fire750, and APC (Table 1). The spectral profile of unstained cells was collected and treated as an independent parameter, which allows the autofluorescence signature to be extracted using the unmixing algorithm. The full emission spectrum of each single-stained sample was performed using compensation beads (OneComp eBeads ${ }^{\mathrm{TM}}$, Thermo Fisher) or PBMCs and was used to determine the contribution of each fluorophore in a mixed sample using spectral deconvolution (unmixing) algorithms before experiments. The fluorophore spectral signatures obtained at the cytometer were compared to the gold standard full-spectrum signatures shown in the Aurora fluorochrome guide (https:/ / cytekbio.com/blogs/resources/51-full-spectrum-cytometry-overview-poster, accessed on 1 November 2021) to ensure fluorophore identity and quality. Post-acquisition, unmixed FCS files were conventionally compensated before the data analysis. The frequency of major immune cell populations was determined using FlowJo ${ }^{\text {TM }}$ Software v10 (BD Biosciences) based on manual gating strategies as reported in the results section.

Table 1. Antibody panel and HLApeptide tetramers used for anti-HCMV immune profiling using spectral flow cytometry. Antigen, fluorophore, clone, and dilution are indicated.

\begin{tabular}{|c|c|c|c|c|c|c|c|}
\hline $\begin{array}{c}\Lambda \\
\text { Excitation }(\mathrm{nm})\end{array}$ & Fluorophore & $\begin{array}{c}\Lambda \\
\text { Emission }(\mathrm{nm})\end{array}$ & $\begin{array}{l}\text { Cytometer } \\
\text { Detector }\end{array}$ & Antigen & $\begin{array}{l}\text { Antibody } \\
\text { Clone }\end{array}$ & Dilution & Source \\
\hline \multirow[t]{6}{*}{355} & BUV395 & 395 & UV2 & CD45RA & $5 \mathrm{H} 9$ & $1 / 80^{e}$ & $\begin{array}{c}\text { BD } \\
\text { Bioscience }\end{array}$ \\
\hline & $\begin{array}{c}\text { Fixable } \\
\text { Viability Dye } \\
\text { UV440 }\end{array}$ & 436 & UV6 & Viability & / & $1 / 2000^{e}$ & $\begin{array}{c}\text { BD } \\
\text { Bioscience }\end{array}$ \\
\hline & BUV496 & 496 & UV7 & CD16 & $3 \mathrm{G} 8$ & $1 / 160^{\mathrm{e}}$ & $\begin{array}{c}\text { BD } \\
\text { Bioscience }\end{array}$ \\
\hline & BUV563 & 564 & UV9 & NKG2C & 134591 & $1 / 20^{e}$ & $\begin{array}{c}\text { BD } \\
\text { Bioscience }\end{array}$ \\
\hline & BUV737 & 735 & UV14 & CD56 & NCAM16.2 & $1 / 20^{\mathrm{e}}$ & $\begin{array}{c}\mathrm{BD} \\
\text { Bioscience }\end{array}$ \\
\hline & BUV805 & 803 & UV16 & CD8 & SK1 & $1 / 80^{e}$ & $\begin{array}{c}\text { BD } \\
\text { Bioscience }\end{array}$ \\
\hline \multirow[t]{6}{*}{405} & BV421 & 421 & V1 & CCR7 & G043H7 & $1 / 20^{e}$ & Biolegend \\
\hline & VioBlue & 452 & V3 & KLRG1 & REA261 & $1 / 50^{\mathrm{e}}$ & Myltenyi \\
\hline & BV510 & 510 & V7 & CD3 & OKT3 & $1 / 20^{e}$ & Biolegend \\
\hline & BV570 & 570 & V8 & CD4 & RPA-T4 & $1 / 80^{\mathrm{e}}$ & Biolegend \\
\hline & BV605 & 603 & V10 & 2B4 & C1.7 & $1 / 80^{\mathrm{e}}$ & Biolegend \\
\hline & BV785 & 785 & V15 & PD-1 & EH12.2H7 & $1 / 10^{\mathrm{e}}$ & Biolegend \\
\hline \multirow[t]{2}{*}{488} & FITC & 520 & B2 & CD57 & HNK-1 & $1 / 160^{\mathrm{e}}$ & Biolegend \\
\hline & PerCPeFluor710 & 710 & B10 & TCRgd & B1.1 & $1 / 20^{\mathrm{e}}$ & $\begin{array}{l}\text { Thermo } \\
\text { Fisher }\end{array}$ \\
\hline \multirow[t]{3}{*}{561} & PE & 576 & YG1 & CD158 & HP-MA4 & $1 / 40^{\mathrm{e}}$ & Biolegend \\
\hline & AlexaFluor594 & 617 & YG3 & NKG2A & 131411 & $1 / 20^{\mathrm{e}}$ & Bio-Techne \\
\hline & PE-Сy7 & 781 & YG9 & CX3CR1 & 2A9-1 & $1 / 20^{e}$ & Biolegend \\
\hline \multirow[t]{2}{*}{640} & SparkNir685 & 685 & R3 & CD19 & HIB19 & $1 / 80^{e}$ & Biolegend \\
\hline & $\begin{array}{c}\text { APC Fire750 } \\
\text { APC }\end{array}$ & $\begin{array}{l}787 \\
660\end{array}$ & $\begin{array}{l}\text { R7 } \\
\text { R1 }\end{array}$ & \begin{tabular}{l}
\multicolumn{1}{c}{ TCRgd2 } \\
Streptavidin \\
HLA $_{\text {peptide }}$
\end{tabular} & $\begin{array}{c}\text { B6 } \\
/\end{array}$ & $\begin{array}{l}1 / 160^{\mathrm{e}} \\
1 / 11^{\mathrm{e}}\end{array}$ & $\begin{array}{c}\text { Biolegend } \\
\text { BD } \\
\text { Bioscience }\end{array}$ \\
\hline / & / & / & / & CD94 & HP-3D9 & $\begin{array}{c}30 \\
\mu \mathrm{g} / \mathrm{mL}\end{array}$ & $\begin{array}{c}\text { BD } \\
\text { Bioscience }\end{array}$ \\
\hline / & / & / & / & Fc block & Fc1.3216 & $1 / 100^{\mathrm{e}}$ & $\begin{array}{c}\text { BD } \\
\text { Bioscience }\end{array}$ \\
\hline
\end{tabular}

\subsection{Statistical Analysis}

Comparisons between groups were represented as box plots showing median, 25th, and 75th percentile values using GraphPad Prism 8.0 software (GraphPad Software Inc., Sand Diego, CA, USA). Comparisons among groups were performed using non-parametric Wilcoxon-Mann-Whitney tests when suitable. Statistical differences were determined 
by GraphPad Prism 8.0. A two-sided $p$ value $<0.05$ was considered to be statistically significant. $p$ value: ${ }^{*}$ for $p<0.05$.

Author Contributions: Conceptualization, B.C., A.R. and L.D.; methodology, A.R. and L.D.; formal analysis, B.C. and A.R.; investigation, A.R., L.D., and M.B.; resources, C.B. and A.R.; writing-original draft preparation, B.C.; supervision, B.C.; funding acquisition, B.C. and C.B. All authors have read and agreed to the published version of the manuscript.

Funding: This research was funded by the Association Grégory Lemarchal and Vaincre la Mucoviscidose (France), grant number RF20190502487, and by l'Institut de Recherche en Santé Respiratoire des Pays de la Loire (France), grant number LSC 10280.

Institutional Review Board Statement: Banked biological samples (PBMCs) were issued from the DIVAT biocollection (CNIL agreement $n^{\circ} 891735$, French Health Minister Project $\left.n^{\circ} 02 G 55\right)$. This retrospective study was performed according to the guidelines of the local and national ethics committees (CCPRB, CHU de Nantes, France). Blood samples collected from anonymous healthy volunteers $(n=25)$ were obtained from the Etablissement Français du Sang (EFS Pays de la Loire, Nantes) with donors' specific and written informed consent for research use.

Informed Consent Statement: Informed consent was obtained from all subjects involved in the study.

Data Availability Statement: Publicly available datasets were analyzed in this study.

Acknowledgments: The authors thank Karine Bernardeau and Klara Echasserieau from the Recombinant Protein Facility $\left(\mathrm{P}^{2} \mathrm{R}\right.$, Structure Fédérative de Recherche "Francois Bonamy", Nantes) for the production of pHLA-E- and pHLA-A*02-tetramers. The authors also thank the Etablissement Français du Sang (EFS, Pays de la Loire, Nantes, France) and the Centre de Ressources Biologiques (CRB, CHU de Nantes, France) for blood sample collection and harvesting. The graphical abstract was drawn using biorender.com.

Conflicts of Interest: The authors declare no conflict of interest. The funders had no role in the design of the study; in the collection, analyses, or interpretation of data; in the writing of the manuscript, or in the decision to publish the results.

\section{References}

1. Boeckh, M.; Geballe, A.P. Cytomegalovirus: Pathogen, paradigm, and puzzle. J. Clin. Investig. 2011, 121, 1673-1680. [CrossRef]

2. Sylwester, A.W.; Mitchell, B.L.; Edgar, J.B.; Taormina, C.; Pelte, C.; Ruchti, F.; Sleath, P.R.; Grabstein, K.H.; Hosken, N.A.; Kern, F.; et al. Broadly targeted human cytomegalovirus-specific CD4+ and CD8+ T cells dominate the memory compartments of exposed subjects. J. Exp. Med. 2005, 202, 673-685. [CrossRef]

3. Kaminski, H.; Garrigue, I.; Couzi, L.; Taton, B.; Bachelet, T.; Moreau, J.F.; Dechanet-Merville, J.; Thiebaut, R.; Merville, P. Surveillance of gammadelta T Cells Predicts Cytomegalovirus Infection Resolution in Kidney Transplants. J. Am. Soc. Nephrol. 2016, 27, 637-645. [CrossRef]

4. Forte, E.; Zhang, Z.; Thorp, E.B.; Hummel, M. Cytomegalovirus Latency and Reactivation: An Intricate Interplay With the Host Immune Response. Front. Cell Infect. Microbiol. 2020, 10, 130. [CrossRef]

5. Klenerman, P.; Oxenius, A. T cell responses to cytomegalovirus. Nat. Rev. Immunol. 2016, 16, 367-377. [CrossRef]

6. Khairallah, C.; Dechanet-Merville, J.; Capone, M. gammadelta T Cell-Mediated Immunity to Cytomegalovirus Infection. Front. Immunol. 2017, 8, 105. [CrossRef]

7. Sylwester, A.; Nambiar, K.Z.; Caserta, S.; Klenerman, P.; Picker, L.J.; Kern, F. A new perspective of the structural complexity of HCMV-specific T-cell responses. Mech. Ageing Dev. 2016, 158, 14-22. [CrossRef] [PubMed]

8. Romagnani, C.; Pietra, G.; Falco, M.; Millo, E.; Mazzarino, P.; Biassoni, R.; Moretta, A.; Moretta, L.; Mingari, M.C. Identification of HLA-E-specific alloreactive T lymphocytes: A cell subset that undergoes preferential expansion in mixed lymphocyte culture and displays a broad cytolytic activity against allogeneic cells. Proc. Natl. Acad. Sci. USA 2002, 99, 11328-11333. [CrossRef]

9. Pietra, G.; Romagnani, C.; Mazzarino, P.; Falco, M.; Millo, E.; Moretta, A.; Moretta, L.; Mingari, M.C. HLA-E-restricted recognition of cytomegalovirus-derived peptides by human CD8+ cytolytic T lymphocytes. Proc. Natl. Acad. Sci. USA 2003, 100, 10896-10901. [CrossRef]

10. Sullivan, L.C.; Westall, G.P.; Widjaja, J.M.; Mifsud, N.A.; Nguyen, T.H.; Meehan, A.C.; Kotsimbos, T.C.; Brooks, A.G. The Presence of HLA-E-Restricted, CMV-Specific CD8+ T Cells in the Blood of Lung Transplant Recipients Correlates with Chronic Allograft Rejection. PLoS ONE 2015, 10, e0135972. [CrossRef]

11. Jouand, N.; Bressollette-Bodin, C.; Gerard, N.; Giral, M.; Guerif, P.; Rodallec, A.; Oger, R.; Parrot, T.; Allarrd, M.; Cesbron-Gautier, A.; et al. HCMV triggers frequent and persistent UL40-specific unconventional HLA-E-restricted CD8 T-cell responses with potential autologous and allogeneic peptide recognition. PLoS Pathog. 2018, 14, e1007041. [CrossRef] 
12. Pietra, G.; Romagnani, C.; Falco, M.; Vitale, M.; Castriconi, R.; Pende, D.; Millo, E.; Anfossi, S.; Biassoni, R.; Moretta, L.; et al. The analysis of the natural killer-like activity of human cytolytic T lymphocytes revealed HLA-E as a novel target for TCR alpha/beta-mediated recognition. Eur. J. Immunol. 2001, 31, 3687-3693. [CrossRef]

13. Allard, M.; Tonnerre, P.; Nedellec, S.; Oger, R.; Morice, A.; Guilloux, Y.; Houssaint, E.; Charreau, B.; Gervois, N. HLA-E-restricted cross-recognition of allogeneic endothelial cells by CMV-associated CD8 T cells: A potential risk factor following transplantation. PLOS ONE 2012, 7, e50951. [CrossRef]

14. Altman, J.D.; Moss, P.A.; Goulder, P.J.; Barouch, D.H.; McHeyzer-Williams, M.G.; Bell, J.I.; McMichael, A.J.; Davis, M.M. Phenotypic analysis of antigen-specific T lymphocytes. Science 1996, 274, 94-96. [CrossRef]

15. Hadrup, S.R.; Bakker, A.H.; Shu, C.J.; Andersen, R.S.; van Veluw, J.; Hombrink, P.; Castermans, E.; Straten, P.T.; Blank, C.; Haanen, J.B.; et al. Parallel detection of antigen-specific T-cell responses by multidimensional encoding of MHC multimers. Nat. Methods 2009, 6, 520-526. [CrossRef]

16. Newell, E.W.; Klein, L.O.; Yu, W.; Davis, M.M. Simultaneous detection of many T-cell specificities using combinatorial tetramer staining. Nat. Methods 2009, 6, 497-499. [CrossRef]

17. Newell, E.W.; Sigal, N.; Nair, N.; Kidd, B.A.; Greenberg, H.B.; Davis, M.M. Combinatorial tetramer staining and mass cytometry analysis facilitate T-cell epitope mapping and characterization. Nat. Biotechnol. 2013, 31, 623-629. [CrossRef]

18. Perfetto, S.P.; Chattopadhyay, P.K.; Roederer, M. Seventeen-colour flow cytometry: Unravelling the immune system. Nat. Rev. Immunol. 2004, 4, 648-655. [CrossRef]

19. Nolan, J.P.; Condello, D. Spectral flow cytometry. Curr. Protoc. Cytom. 2013, 1, 1-27. [CrossRef]

20. Karrer, U.; Sierro, S.; Wagner, M.; Oxenius, A.; Hengel, H.; Koszinowski, U.H.; Phillips, R.E.; Klenerman, P. Memory inflation: Continuous accumulation of antiviral CD8+ T cells over time. J. Immunol. 2003, 170, 2022-2029. [CrossRef]

21. Meyer-Olson, D.; Simons, B.C.; Conrad, J.A.; Smith, R.M.; Barnett, L.; Lorey, S.L.; Duncan, C.B.; Ramalingam, R.; Kalams, S.A. Clonal expansion and TCR-independent differentiation shape the HIV-specific CD8+ effector-memory T-cell repertoire in vivo. Blood 2010, 116, 396-405. [CrossRef]

22. O'Hara, G.A.; Welten, S.P.; Klenerman, P.; Arens, R. Memory T cell inflation: Understanding cause and effect. Trends Immunol. 2012, 33, 84-90. [CrossRef]

23. Van den Berg, S.P.H.; Pardieck, I.N.; Lanfermeijer, J.; Sauce, D.; Klenerman, P.; van Baarle, D.; Arens, R. The hallmarks of CMV-specific CD8 T-cell differentiation. Med. Microbiol. Immunol. 2019, 208, 365-573. [CrossRef]

24. Derhovanessian, E.; Maier, A.B.; Hahnel, K.; Beck, R.; de Craen, A.J.M.; Slagboom, E.P.; Westendorp, R.G.J.; Pawelec, G. Infection with cytomegalovirus but not herpes simplex virus induces the accumulation of late-differentiated CD4+ and CD8+ T-cells in humans. J. Gen. Virol. 2011, 92, 2746-2756. [CrossRef]

25. Dechanet, J.; Merville, P.; Berge, F.; Bone-Mane, G.; Taupin, J.L.; Michel, P.; Joly, P.; Bonneville, M.; Potaux, L.; Moreau, J.-F.; et al. Major expansion of gammadelta T lymphocytes following cytomegalovirus infection in kidney allograft recipients. J. Infect. Dis. 1999, 179, 1-8. [CrossRef]

26. Stankovic, S.; Davey, M.S.; Shaw, E.M.; von Borstel, A.; Cristiano, Y.; Levvey, B.J.; Rossjohn, J.; Westall, G.P.; Snell, G.I.; Brooks, A.G.; et al. Cytomegalovirus replication is associated with enrichment of distinct gammadelta T cell subsets following lung transplantation: A novel therapeutic approach? J. Heart Lung Transpl. 2020, 39, 1300-1312. [CrossRef]

27. Alejenef, A.; Pachnio, A.; Halawi, M.; Christmas, S.E.; Moss, P.A.; Khan, N. Cytomegalovirus drives Vdelta2neg gammadelta T cell inflation in many healthy virus carriers with increasing age. Clin. Exp. Immunol. 2014, 176, 418-428. [CrossRef]

28. Couzi, L.; Pitard, V.; Moreau, J.F.; Merville, P.; Dechanet-Merville, J. Direct and Indirect Effects of Cytomegalovirus-Induced gammadelta T Cells after Kidney Transplantation. Front. Immunol. 2015, 6, 3. [CrossRef]

29. Della Chiesa, M.; Marcenaro, E.; Sivori, S.; Carlomagno, S.; Pesce, S.; Moretta, A. Human NK cell response to pathogens. Semin. Immunol. 2014, 26, 152-160. [CrossRef]

30. Cichicki, F.; Schlums, H.; Theorell, J.; Tesi, B.; Miller, J.S.; Ljunggren, H.G.; Bryceson, Y.T. Diversification and Functional Specialization of Human NK Cell Subsets. Curr. Top. Microbiol. Immunol. 2016, 395, 63-94.

31. Freud, A.G.; Mundy-Bosse, B.L.; Yu, J.; Caligiuri, M.A. The Broad Spectrum of Human Natural Killer Cell Diversity. Immunity 2017, 47, 820-833. [CrossRef]

32. Roberto, A.; Di Vito, C.; Zaghi, E.; Mazza, E.M.C.; Capucetti, A.; Calvi, M.; Tentorio, P.; Zanon, V.; Sarina, B.; Mariotti, J.; et al. The early expansion of anergic NKG2A(pos)/CD56(dim)/CD16(neg) natural killer represents a therapeutic target in haploidentical hematopoietic stem cell transplantation. Haematologica 2018, 103, 1390-1402. [CrossRef]

33. Di Vito, C.; Mikulak, J.; Mavilio, D. On the Way to Become a Natural Killer Cell. Front. Immunol. 2019, 10, 1812. [CrossRef]

34. Ferrer-Font, L.; Mayer, J.U.; Old, S.; Hermans, I.F.; Irish, J.; Price, K.M. High-Dimensional Data Analysis Algorithms Yield Comparable Results for Mass Cytometry and Spectral Flow Cytometry Data. Cytom. A 2020, 97, 824-831. [CrossRef]

35. Ferrer-Font, L.; Pellefigues, C.; Mayer, J.U.; Small, S.J.; Jaimes, M.C.; Price, K.M. Panel Design and Optimization for HighDimensional Immunophenotyping Assays Using Spectral Flow Cytometry. Curr. Protoc. Cytom. 2020, 92, e70. [CrossRef]

36. Braud, V.M.; Allan, D.S.; O'Callaghan, C.A.; Soderstrom, K.; D’Andrea, A.; Ogg, G.S.; Lazetic, S.; Young, N.T.; Bell, J.I.; Phillips, J.H.; et al. HLA-E binds to natural killer cell receptors CD94/NKG2A, B and C. Nature 1998, 391, 795-799. [CrossRef]

37. Arlettaz, L.; Villard, J.; de Rham, C.; Degermann, S.; Chapuis, B.; Huard, B.; Roosnek, E. Activating CD94:NKG2C and inhibitory CD94:NKG2A receptors are expressed by distinct subsets of committed CD8+ TCR alphabeta lymphocytes. Eur. J. Immunol. 2004, 34, 3456-3464. [CrossRef] 
38. Jiang, H.; Canfield, S.M.; Gallagher, M.P.; Jiang, H.H.; Jiang, Y.; Zheng, Z.; Chess, L. HLA-E-restricted regulatory CD8(+) T cells are involved in development and control of human autoimmune type 1 diabetes. J. Clin. Investig. 2010, 120, 3641-3650. [CrossRef] [PubMed]

39. La Manna, M.P.; Orlando, V.; Prezzemolo, T.; Di Carlo, P.; Cascio, A.; Delogu, G.; Poli, G.; Sullivan, L.C.; Brooks, A.G.; Dieli, F.; et al. HLA-E-restricted CD8(+) T Lymphocytes Efficiently Control Mycobacterium tuberculosis and HIV-1 Coinfection. Am. J. Respir. Cell Mol. Biol. 2020, 62, 430-439. [CrossRef]

40. Coupel, S.; Moreau, A.; Hamidou, M.; Horejsi, V.; Soulillou, J.P.; Charreau, B. Expression and release of soluble HLA-E is an immunoregulatory feature of endothelial cell activation. Blood 2007, 109, 2806-2814. [CrossRef]

41. Holderried, T.A.; Lang, P.A.; Kim, H.J.; Cantor, H. Genetic disruption of CD8+ Treg activity enhances the immune response to viral infection. Proc. Natl. Acad. Sci. USA 2013, 110, 21089-21094. [CrossRef] [PubMed]

42. $\quad$ Lopez-Verges, S.; Milush, J.M.; Schwartz, B.S.; Pando, M.J.; Jarjoura, J.; York, V.A.; Houchins, J.P.; Miller, S.; Kang, S.-M.; Norris, P.J.; et al. Expansion of a unique CD57(+)NKG2Chi natural killer cell subset during acute human cytomegalovirus infection. Proc. Natl. Acad. Sci. USA 2011, 108, 14725-14732. [CrossRef] [PubMed]

43. Gratama, J.W.; Boeckh, M.; Nakamura, R.; Cornelissen, J.J.; Brooimans, R.A.; Zaia, J.A.; Forman, S.J.; Gaal, K.; Bray, K.R.; Gasior, G.H.; et al. Immune monitoring with iTAg MHC Tetramers for prediction of recurrent or persistent cytomegalovirus infection or disease in allogeneic hematopoietic stem cell transplant recipients: A prospective multicenter study. Blood 2010, 116, 1655-1662. [CrossRef]

44. Jarque, M.; Crespo, E.; Melilli, E.; Gutierrez, A.; Moreso, F.; Guirado, L.; Revuelta, I.; Montero, N.; Torras, J.; Reira, L.; et al. Cellular Immunity to Predict the Risk of Cytomegalovirus Infection in Kidney Transplantation: A Prospective, Interventional, Multicenter Clinical Trial. Clin. Infect. Dis. 2020, 71, 2375-2385. [CrossRef] [PubMed] 